\title{
CLASICISMO, ROMANTICISMO Y LAS UVAS DORADAS: LA GENERACIÓN LITERARIA HACE CINE
}

\author{
David Felipe ARRANZ LAGO \\ Universidad Carlos III de Madrid \\ darranz@hum.uc3m.es
}

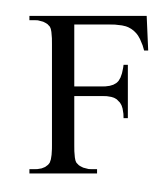

ue un momento trascendental de nuestro cine, aunque quizá se venía gestando desde que Jacinto Benavente y los hermanos Álvarez Quintero fundaron los Estudios CEA el 17 de marzo de 1932. Nuestro cine era en aquel momento una cuestión de pioneros vinculados al mundo de la literatura: los autores más respetados y exitosos se sintieron atraídos por un recién llegado que emparentaba en un grado extraordinario con sus narrativas, a tal punto que era obvio que por fin podían animar, dar forma y volumen a las historias y personajes que habían volcado sobre el teatro o, simplemente, sobre el papel. El celuloide pegaba fuerte sobre el tapizado madrileñista del folletín y los sainetes, pero a lo largo del siglo XX aquellos sueños de tinta y celuloide verían mermado su impulso creativo por culpa de la censura, especialmente en el caso de espíritus libres como el del recientemente fallecido cineasta Basilio Martín Patino (1930-2017), cuya trayectoria cinematográfica, una lucha constante contra los censores, analizaremos aquí no sin antes hacer algunas calas por nuestro mejor cine literario, aquellos románticos que, sin duda, nacieron ya son clásicos.

Demos un salto un par de décadas. En aquel singular balcón de las letras con vistas al invento de los hermanos Lumière, Fernando Fernán Gómez debutó en la dirección cinematográfica con Manicomio (1953), película producida por Helenia Films e inspirada en relatos de Edgar Allan Poe, Leónidas Andreiev y Ramón Gómez de la Serna. Pero aquella adaptación le hacía al Régimen un ruido sin duda protestón y la escritura del guión fue sometida a un severo recorte por parte de la censura. Según refiere el propio Fernán Gómez, «el guión fue prohibido totalmente, lo autorizaron con cortes, hubo que luchar mucho. La razón que nos dijeron fue que el tema de la locura no podía tomarse a broma. Esto, en el país de don Quijote, me parecía absurdo» (Marías y Martínez Torres, 1970: 59). Finalmente, la película fue codirigida por Luis María Delgado, y a esta excelente y singular cinta le siguieron, también dirigidas por el genial intérprete, una serie de brillantes títulos que trasladaban obras literarias de célebres escritores: El malvado Carabel (1956) -Wenceslao Fernández Flórez-, Sólo para hombres (1960) -Miguel Mihura-, La venganza de don Mendo (1961) 
-Pedro Muñoz Seca-, El mundo sigue (1963) -Juan Antonio Zunzunegui-, Los Palomos (1964) Alfonso Paso-, Ninette y un señor de Murcia (1965) -Miguel Mihura-, Mayores con reparos (1966) -Juan José Alonso Millán-, Cómo casarse en siete días (1971) -Alfonso Paso-, El viaje a ninguna parte (1986) -Fernando Fernán Gómez-, El mar y el tiempo (1989) -Fernando Fernán Gómez- y Lázaro de Tormes (2001) -basada en la obra anónima-. Valga esta muestra para recordar una edad de oro del cine español en la que el celuloide enarboló la bandera de la literatura y que se desarrolló, en el estricto ámbito artístico, de la floreciente II República al comienzo del siglo XX, pasando por las desiguales cuatro décadas de Franquismo y la más que irregular Transición con la honestidad estética que se le permitió y una brillantez que jamás se dejó amaestrar, pero que hubo de andar, díscola, de puntillas por la galería de los generales con unos fotogramas elegantes y democráticos si exceptuamos las producciones de CEA creadas para exaltación del Régimen.

Más allá del reconocimiento de esta asfixia promovida por el Régimen, generalmente se cae exclusivamente en un tono político a la hora de analizar nuestro cine, un sesgo que nos sustrae sus verdaderos logros y sus preocupaciones profundas, y pocas veces se tienen la paciencia y la imparcialidad suficientes para realizar un acercamiento a lo estrictamente literario, por ejemplo. Cierto es que la cinematografía española, diseñada como una industria piadosamente feliz después de la Guerra Civil, con el tiempo y el debilitamiento del franquismo vino a convertirse en el cine torneado y de autor que hizo eclosión en paralelo al «landismo». Muestra de ello, de un continuum de excelencia que recorre los dos últimos tercios del siglo XX, es el cine no sólo de Fernán Gómez, sino el de Juan Antonio Bardem, Carlos Saura, Basilio Martín Patino, Jaime Camino, Víctor Erice, Jaime de Armiñán, Francisco Regueiro, Gonzalo Suárez, Miguel Picazo, Joaquín Jordá o Luis García Berlanga. Recientemente hemos vuelto a ver Don Juan en los infiernos (1991), de Gonzalo Suárez, con ocasión del cotejo con el guión original coescrito por su director y Azucena Rodríguez Pomeda, atendiendo al drama de Molière, y publicado ese mismo año (Suárez, 1991). Se trata de un filme complejo y alegórico que, amén del trabajo literario de su autor, cuenta con una extraordinaria fotografía de Carlos Suárez y una soberbia puesta en escena que recrea la España de Felipe II. Podríamos estar hablando de una de las escasas películas españolas que a finales del siglo XX abría un portillo insólito a la literatura, recuperando los modos y maneras del cine de arte y ensayo que tanto gustó a los intelectuales de los años 60, en la frontera de dos siglos. Gracias al esfuerzo independiente y profundamente literario de Gonzalo Suárez, quien ha desarrollado en paralelo una excelente carrera como escritor, el cine pudo seguir creciendo y salir de una desolación creativa que, paradójicamente, era la posta del tiempo: las adaptaciones literarias de Rafael Gil, César Fernández Ardavín o Edgar Neville eran la telegrafía venidera.

Y lo mismo podría decirse de la melancólica Madrid (1987), de Basilio Martín Patino, formidable experimento a caballo entre el documental y la ficción que da como resultado un verdadero poema en prosa en imágenes, con el protagonismo de un habitual de Wim Wenders, Rüdiger Vogler, en la piel de un periodista que ha de realizar un programa de televisión con motivo del cincuentenario de la guerra civil, amén de una jugosa intervención del filósofo Carlos París 
definiendo Madrid desde la terraza del Edificio España. También Víctor Erice, José Luis Egea y Claudio Guerín trazaron una ejemplar definición en Los desafíos (1969), producida por Elías Querejeta, de la idiosincrasia española y un estudio de la violencia a través de tres capítulos sobre estallidos silenciosos en los estertores del Franquismo y sexualidades de repentino erguimiento en medio del campo. Todo ello impulsó un clima moral, especialmente en las generaciones más jóvenes de la burguesía, que desarrollaban un talante liberal a través del cine y la literatura, coincidente de lleno con la llamada Generación del Medio Siglo. De hecho, Jesús Fernández Santos, autor de Extramuros, Cabrera o Los jinetes del alba, llegó a dirigir más de cien documentales y una excelente película de ficción: Llegar a más (1961). Parecido es el caso de Claudio Guerín, que dirigió La casa de las palomas (1971) y la magnífica La campana del infierno (1973), coproducción hispanofrancesa en cuyo rodaje Guerín perdió la vida accidentalmente, truncándose así una prometedora carrera. El cineasta se precipitó desde el campanario de la iglesia de Noya durante la filmación y Bardem hubo de terminar la película, dando así pie a la leyenda de un título maldito... al punto de que sólo existe hoy una edición francesa de la película en DVD.

Recordemos aquí oportunamente el papel esencial de los desaparecidos cineclubes, como el madrileño Cineclub Vinces que coordinaba Juan Cobos, y que aglutinaron una interesante reflexión cineclubista en torno a cineastas, libros y revistas como Objetivo -que se prohibió en 1955-, actividad que hoy ha desaparecido sin dejar rastro. El diario Madrid denunció el 13 de febrero de 1960 la exhibición en varios cineclubes de El acorazado Potempkin, «la apología de la revolución rusa», desencadenando una campaña de prensa que se centró en calificar estos foros como centros subversivos y que fue secundada por el diario $A B C$, el 20 de febrero: «¿Qué público acoge en su seno el innominado club, dispuesto a tolerar, benévolo, la exhibición de una película tan dinamitera y destructiva?».

Sin duda, en este contexto, nuestros cineastas encontraron la forma adecuada de interpretar las obras literarias en la gran pantalla, siempre que los censores lo permitiesen. Tal es el caso de la versión que iba a filmar Fernando Fernán Gómez de La familia de Pascual Duarte, basada en la obra homónima de Cela, o la adaptación de El río que nos lleva, novela de José Luis Sampedro, que iba a llevar a cabo Luis García Berlanga con el título Los gancheros y que, finalmente, se adaptó en 1989 de forma muy correcta. Aquellos guiones escritos al comienzo de la década de los años 60 se perdieron para siempre y constituyen la imagen borrada que despierta cierta nostalgia por aquellas películas pensadas para ampliar el significado de la obra literaria original y que finalmente filmaron Ricardo Franco y Antonio del Real, respectivamente.

Disponemos, sin embargo, de la información suficiente para saber cómo deseaba Marco Ferreri que acabasen dos joyas como El pisito (1958) y El cochecito (1960): en la primera, Rodolfo iba a conocer la felicidad al contraer matrimonio con la anciana y heredar la vivienda, y en la segunda, el anciano consumaba el asesinato colectivo de su familia y era detenido por la Guardia Civil, pero ambos fueron alterados por la censura y a Ferreri no se le renovó su permiso de residencia en España. Otro de los proyectos que, por culpa de la censura, jamás llegó a rodarse fue la atractiva 
Jimena, a partir del Cantar de Mío Cid, y que iba a producir Ferreri con guión de Miguel Picazo, Mario Camus, Francisco Regueiro y Joaquín Jordá. La Diputación de Jaén ha editado en 2015 una copia del guión, que desmitifica el personaje glorificado por Anthony Mann, y cuya fuerza e ingenio antiheroico lo harían candidato a ser puesto en imágenes en nuestros días. También el desenlace de Viridiana (1961), que concluía en realidad con Viridiana (Silvia Pinal) convertida en amante de Jorge (Francisco Rabal), fue oportunamente modificado por la censura, que sin querer cerró así la película con un ménage à trois entre Jorge, Viridiana y Ramona.

Volviendo a Basilio Martín Patino, el universo de autor de Nueve cartas a Berta (1966), genuino cineasta español cuya formidable e innovadora obra fue una de las puntas de lanza del llamado nuevo cine español. Y el espectador que se acerque a este documento de sentida admiración descubre por primera vez que detrás del título clave de las Nueve cartas a Berta se encuentra nada menos que el poema «Españolito», perteneciente a Campos de Castilla, de Antonio Machado: «Españolito que vienes / al mundo te guarde Dios. / Una de las dos Españas / ha de helarte el corazón». Su obra reúne un total de dieciocho largometrajes para cine y televisión, además de varios cortometrajes de extraordinario valor estético y cinematográfico, como Imágenes sobre un retablo (1955), Tarde de domingo (1960) -su trabajo de fin de carrera, que recoge la frustración de una mujer sola, en su casa-, El noveno (1961), Torerillos 61 (1961), Imágenes y versos de la Navidad (1962), Rinconete y Cortadillo (1967), Paseos por los letreros de Madrid (1968), Hombre y ciudad (1980) o Retablo de la Guerra Civil española (1980).

Queridísimos verdugos fue rodada de forma clandestina en 1971, ofrece tres entrevistas a sendos verdugos - que aún ajusticiaban con el garrote vil a comienzos de los años 70- y a los familiares de los ajusticiados, y se estrenó muy tardíamente en 1977. Los otros dos títulos que Basilio Martín Patino rodó en la clandestinidad, Canciones para después de una guerra (1971) y Caudillo (1974), atestiguan unos inicios en el cine provocadores y políticamente comprometidos con la revisión histórica, simplemente a través de la particular sintaxis de unas imágenes seleccionadas de forma brillante y que conforman la memoria de la España de Franco. Sin embargo, el hombre que dejó varias veces el cine porque necesitaba un descanso desconfiaba ante todo de las películas testimoniales; en ese sentido, su cine no pretende en ningún momento moralizar. Para Martín Patino en ese tipo de películas suele haber una especie de voluntarismo excesivo, una suerte de autoridad propia de quien se sube al púlpito: «La realidad española es más compleja. El molde negativo de esa realidad que no aparece dice tanto como lo apariencial», comenta en una entrevista de 1982 hasta la fecha inédita, cuando la recupera Virginia García del Pino en su documental Basilio Martín Patino. La décima carta (2014).

Queridísimos verdugos es el contralienzo de celuloide, la respuesta cinematográfica a una investigación, Los verdugos españoles (1971), del periodista Daniel Sueiro, y que junto a La pena de muerte (1973), ensayo del mismo escritor, constituye un impresionante tríptico que idearon juntos a caballo entre el cine y la crónica. Para el cineasta, el proyecto supuso una suerte de liberación en un tiempo tan duro y, a la vez, la película más difícil que hizo, pues había que quitar el sadismo y la 
brutalidad de un hecho, el de la ejecución de la pena capital, esencialmente despiadado. Por un lado, tenía que andar con mucho cuidado de no despertar el recelo de los censores o incluso de las autoridades civiles; y, por otro, quería soslayar aspectos inherentes al oficio de estos verdugos como el sadismo o lo macabro. El resultado de ese difícil equilibrio fue una película que Martín Patino ha reconocido siempre que no sería capaz de volver a hacer. En cualquier caso, Queridísimos verdugos es, en realidad el capítulo «Garrote vil» de una serie de una serie más ambiciosa, episodio especialmente destacado por el director salmantino porque representaba a su parecer la cristalización de la pena de muerte, «el resorte de los tiranos para quitarse de en medio a los enemigos». Así, en el documental mencionado, García del Pino va motivando paulatinamente a un cineasta que no desea especialmente revisar su legado y consigue que Martín Patino con la ayuda de su mujer Pilar y de la propia documentalista recuperen los guiones antiguos de lo que iba a ser una serie sobre la pena capital. «Decapitación», «Crucifixión», «Cámara de gas», «Enterramiento en vida» o «Agua» son algunos de los sugerentes guiones que jamás vieron la luz en la gran pantalla. Podemos incluso escuchar de boca del cineasta un fragmento del primero de los guiones, del que afirma ya no acordarse: «Cortarle a un hombre la cabeza, decapitarlo, es además de acabar con su vida, patetizar hasta la evidencia más irrefrenable el hecho certísimo de que aquel cuerpo descabezado ya nunca más volverá a vivir».

La idea germinal de Queridísimos verdugos fue de César Fernández Ardavín, quien siendo profesor del Instituto de Investigaciones y Experiencias Cinematográficas propuso a Martín Patino y a Manuel Summers seguir la pista en Cáceres de uno de los últimos verdugos del Franquismo. Y ante la potencial dificultad de que los ejecutores de la pena capital se negasen a dejarse entrevistar ante la cámara, Basilio Martín Patino descubrió que la vanidad de estos personajes allanó el camino.

«Quizá a mí, que soy sentimental, me impresiona brutalmente la ejecución anónima de un pobre ratero asustado e indefenso», responde a un periodista que lo entrevista en Interviú al poco tiempo de su estreno, tal y como lo recoge García del Pino. Lo cierto es que una de las preocupaciones del cineasta salmantino han sido siempre los heterodoxos, convertidos en material artístico y en documento filmado. En 1982 escribe y dirige junto a José Luis García Sánchez «Inquisición y libertad», y en este corto el narrador comenta:

Disentir implica enfrentarse a muerte en la lucha por la supervivencia de unas ideas. Disentir es cuando menos marginarse hostilmente de los demás o exponerse a ser marginado, recluido como peligroso o totalmente eliminado. A cualquier sistema de poder constituido le atemorizan los grupos automarginados. Definirse en singular practicando el distanciamiento del contexto social provoca el conflicto eterno de ser interpretado por el poder como elemento peligrosamente disgregador y obliga a que se decrete la persecución del disidente como enemigo de los altos intereses de la colectividad.

Podría leerse entre líneas la propia interpretación que hace el director de La seducción del caos de su propia trayectoria creativa, completamente al margen de la cinematografía oficial, no solo durante el Régimen de Franco, sino a través de los sucesivos gobiernos desde la Transición. Su estilo es único y lo definen el dominio del montaje, el uso de la mezcla de propuestas narrativas diferentes, la utilización de los medios de comunicación como soporte -en especial de la televisión-, el uso de 
la voz en off, y sobre todo el recurso del documento físico -fotografías, cartas, archivos, libros, fragmentos de películas...- como vía natural para dar coherencia y dinamizar el relato. En el documental de García del Pino, durante la ceremonia de coronación de Felipe VI, Martín Patino señala: «¿Qué hay de España? No hay gente que analice esto ahora ya. Porque esta imagen retórica es una comedia total. La gente se adapta al espectáculo, es un teatro bonito que reproducen a toda costa. Pero ¿qué hay aquí?, ¿qué hay detrás de todo esto?».

Fue el director de Nueve cartas a Berta el cronista de un desgarro, del regreso de los intelectuales exiliados, de las divinas nostalgias de Los paraísos perdidos a lo Alberti, el detective de los lugares secretos de la Celestina, el incansable lector de periódicos que luego filmaba a tres o cuatro columnas con daguerrotipo de ajusticiado para la gran pantalla...

Pocos como él han entendido el rastro fugaz, apasionado, eléctrico y efímero del periodismo. Pero para él tenían el mismo interés un documento del Santo Oficio, las Confesiones de San Agustín o las páginas del diario El Alcázar. Porque Basilio tomaba los símbolos sacralizados por el Régimen y les devolvía en el cine a su miseria esencial con extraordinaria elegancia. Caudillo (1977) es el documental más fino y perspicaz jamás filmado de cuatro décadas de podredumbre dictatorial, igual que Canciones para después de una guerra (1971) pone música a la tragedia cainita de todo un pueblo que, tras la sublevación de unos militares rebeldes y facciosos, decidió ajustarse las cuentas.

Recordemos Los pájaros de Baden-Baden (1975), de Mario Camus, después de leer a Ignacio Aldecoa, y a la francesa Catherine Spaak paseando su esbeltez apabullante por el paseo de Pintor Rosales y enloqueciendo de amor a Frédéric de Pasquale. Camus fue ayudante de dirección de Martín Patino en sus primeros cortometrajes, aquellos ejercicios de la Escuela Oficial de Cine de Madrid que hoy lucen como obras maestras, y el cine de ambos, como el de Saura o el de José Luis Borau lleva la impronta de lo esencial, la cantadora de crímenes en la puerta del Sol, las parejas que se hurtaban los besos en la plaza de Oriente delante de los «grises». La literatura, en definitiva, que fue el estudio de todos ellos: por la filmografía de Basilio alumbra el farallón de lecturas de nuestros clásicos, especialmente de Cervantes y Quevedo. Comentaba el maestro en la mesa redonda «El verdugo: un oficio del siglo XX», celebrada en el Instituto Cervantes de Nueva York el 15 de diciembre de 2011, que España sigue siendo el mismo país de pícaros de los siglos XVI y XVII. No podía ser de otra forma para quien se movió entre el empedrado de la muy noble Salamanca, el altarcito barroco, los puestos de la plaza Mayor, el oratorio viejo y el magnesio del fotógrafo suburbial. El 27 de septiembre de ese año de 1975 se produjeron las últimas ejecuciones del franquismo en Madrid, Barcelona y Burgos, y Basilio Martín Patino había ido con su cámara a entrevistar de manera clandestina a los últimos verdugos españoles en el invierno de hacía cinco años. Faltaban aún tres para el estreno de Queridísimos verdugos, en 1977, para muchos, su obra maestra.

Basilio Martín Patino andaba montando Queridísimos verdugos y merced a su curiosidad, que discurría en su día a día como decenas de afluentes, almacenaba y ensamblaba a la vez lo que él llamaba «materiales para una historia de» esto o lo otro y que se incluyen como extras en las 
exquisitas ediciones de sus películas en DVD, ya descatalogadas, y que sacó a la luz Suevia Films bajo la supervisión del cineasta. Sólo conocemos un caso semejante de dispersión gozosa y de work in progress: el de Orson Welles. El cine de ambos tiene ese sabor torrefacto de lo clásico nada más ser concebido, lo inacabado con su efluvio de fotografía sucia, rasgada por el rodillo del proyector y, sin embargo, tan nítida e inteligible... Nadie como él retrató a los españoles trajinados por una guerra civil y estafados por una democracia de salón y burguesa, de paletos reconfortados en los sillones de las cortes. Tampoco nadie ha sabido criticar como él en España el fogonazo falaz de los medios de comunicación como puede verse en la deliciosa La seducción del caos (1990), inspirado nada menos que en El retablo de Maese Pedro de Falla y en el que Adolfo Marsillach hace de Adolfo Marsillach. El trampantojo y el falso documental alcanzaron su cénit en obras maestras como Silverio, El museo japonés y El jardín de los poetas -acaso la mejor, cuando los expertos hablan del hipotético intercambio de los prisioneros Lorca y Primo de Rivera-, películas producidas para la televisión bajo el título «Andalucía, un siglo de fascinación».

También quiso dejar retrato de la generación imposible, malamente matrimoniada bajo los sacrosantos sacramentos y obligada a soportarse, en una película que incomodó a muchos: Del amor y otras soledades (1969), con una Lucía Bosé y un Carlos Estrada verdaderamente desquiciados por tanto éxito, perfección y aburrimiento. Un escándalo en medio del aséptico tálamo conyugal, que resultó ser un teatrillo rancio de aureola triste, entre la urbanización y las torres de Azca, con chica para todo inclusive. Así Basilio enredó a la España tardofranquista levantando olores de cloaca allí donde las parejas perfectas lucían grifería de oro y tarima flotante, escaleras al piso de arriba y esos dos perrazos que lo ponen tibio a uno nada más verlo y hay que consentir porque los anfitriones son ricos y muy burgueses. Ese galernazo de otoño del amor lo lanzó Basilio sin compasión, cuando ya nos creíamos inmunes al desamor y nos lo pintó con sus grietas y ese clima insoportable y cotidiano de trampa y cartón. El estreno provocó una oleada de divorcios y separaciones. Lo normal para una película cargada de derrota y de silencios. Buñuel hizo otro tanto en El discreto encanto de la burguesía (1972), pero dando rienda suelta a la vanguardia salvaje que el aragonés llevaba en el cuerpo. «Hubo una vez en España un hombre enviado por el demonio, que se llamó San Luis Buñuel. Pienso que con él, con nuestro único homo cinematograficus, fruto de estos páramos, de estas historias, bajo estos techos racionalmente angostos, ante esta imposibilidad católica de ser, con sus huidas y sus semirregresos, con su lejanía y con su multipresencia, desde la universal Calanda a la pequeña burguesía de las cinematecas de París, dio de sí nuestro cinema todo lo que podía dar», escribe Basilio en mayo del 68.

Conocía muy bien cada piedra y cada tradición de la localidad salmantina de Lumbrales que lo vio nacer, pero él fue un practicante de un madrileñismo no convencional, capaz de entrever el mundo secreto de los recuerdos. La secuencia de Madrid en la que Rüdiger Vogler monta en paralelo el fragmento del documental del Madrid bombardeado y el actual es impagable y vale para explicar el cinturón de miseria política que aún coleaba en la España de la década de los 80 y del «iOTAN no! ¡Bases fuera!», manifestación que filma el protagonista en la calle de Alcalá -los límites se 
desdibujan- y que la historia nos ha enseñado que de poco sirvió. Madrid era todavía, hacia 1987, una ciudad asaltada por la bendita Movida, atravesada por un fulgor literario y musical, entre la canción protesta y los primeros punkis. Y Martín Patino, con su cámara, hizo televisión dentro del cine, trajo corresponsales, rodó verbenas estivales, iluminó la intimidad de las callejas de los Austrias, en su discreta lucha artística por las ideas libertarias desde la barricada elegante del celuloide. De igual forma, en Los paraísos perdidos la entrada de Charo López a la casona familiar después de tantos años conmociona por la intensidad de los recuerdos, convertidos en un arroyo de aguas turbias y vocaciones dulces y cubiertas de polvo. Ella se pregunta por su padre, fallecido al otro lado del Atlántico, y si realmente mereció la pena tanta integridad.... para nada. El temblor de esta película forma díptico con Octavia (2002), con el regreso del activista político a Salamanca a dar un ciclo de conferencias, a ser entrevistado, a recibir, en definitiva, el reconocimiento que le fue negado a otros. La mirada de Martín Patino es afrancesada, como la de un prodigioso Jean-Luc Godard, aunque también podría ser inglesa, muy Joseph Losey, o alemana, como la de Wim Wenders, todos determinados por el signo de Saturno y la melancolía, con una revolución por dentro, como los protagonistas de Octavia y de La seducción del caos, esparciendo sus dudas y cuestionándose todo en el regazo mismo del set de televisión.

Basilio Martín Patino filmó el paraíso pobre que fuimos, pero también en Libre te quiero (2012) la ilusión del 15-M que cristalizó en un partido político cada vez más alejado del espíritu de los indignados y más próximo y prójimo de la casta. Porque siempre fue joven, se mezcló con 82 años entre los suyos, día y noche, y acampó frente a Tío Pepe velando las armas de la protesta. Aquella era otra España, acaso más verdadera y trágica que ésta, porque se vivía en el fragor del recuerdo reciente de la herida, en la infancia perdida y después recobrada en el cine, en las hogueras inquisitoriales que tanto le interesaron y que documentó como nadie, en el paso ilusionado de la chavalería y de los torerillos que acudían de madrugada al tentadero salmantino, cuando rompía el alba, o en el salto desconfiado de un perro cojo que atraviesa la angostura de un callejón... La suya fue una resistencia, una insumisión permanente y dignísima lejos de las alharacas de los festivales de cine y las revistas. La nueva hornada de directores lampiños parece un chiste con sus monstruos de pacotilla y gritos fantasmales al lado del monumental legado del salmantino, de mirada azul y retrospectiva.

«En el fondo quizá solo sea un romántico, aficionado a las ruinas. Yo mismo a lo mejor no soy también más que la herencia de otras ruinas...», escuchamos de Lorenzo en Nueve cartas a Berta. Esa España de escombros que tanta poesía inspiró a Basilio Martín Patino, las nueve epístolas que Emilio Gutiérrez Caba le escribió desde la Salamanca menestral a su amada Berta, hija de exiliado que vive en Inglaterra, tan lejos, Berta amor mío, ya no existe. Aquellos amores finos, secretos e inconfesables, casi sin palabras... ubi sunt?

El cine español es casi un concepto metafísico, ácrata y heterodoxo, un cine para leer y para pensar, donde Buñuel, Fernando Fernán Gómez, Javier Aguirre, Francisco Regueiro, Miguel Picazo, Carlos Saura, Mario Camus, Josefina Molina, Gonzalo Suárez o Basilio Martín Patino pusieron 
primero sobre el papel y después sobre el celuloide sus sueños de la razón. Benditas películas las de los santos maestros ácratas del celuloide hispánico que han disuelto la esclerosis mental de esta sociedad nuestra tan dada a lo atávico. El cine de Luis García Berlanga que no se olvide, porque el suyo era un cine emparentado con el de Fellini o Ferreri: rococó, transgresor y canalla, muy a la europea. Ahora Europa se parece mucho al suspense de calidad, que lo ruedan de la misma forma en Suecia que en Corea del Sur y no se distingue, que era lo bonito de los festivales internacionales y del Goya a la Mejor Película Europea, con los aplausos en el graderío para Verhoeven o Haneke, que queda muy progre y cultureta aunque no hayan visto sus películas -que el majismo castizo no se lleva bien con Bruselas, que cae muy lejos-. Pero también los maravillosos filmes de los «fernandos»-Colomo, Trueba y Méndez Leite-, los Manuel Gutiérrez Aragón, las Pilar Miró, los Emilio Martínez-Lázaro, los «joseluises»-José Luis Garci, José Luis Cuerda y José Luis García Sánchez- van ganando con el tiempo esa pátina quintaesencial que nos define, porque ver a Resines en Nueva York en la deliciosa La línea del cielo es como ver el álbum de familia. Desde La edad de oro a El ángel exterminador, el cine de Luis Buñuel se ha referido al universo de Goya, en concreto a los Caprichos; e inmerso en leyendas, supersticiones, hechicerías y pantomimas, nuestro blanco y negro se fue (nos fue) haciendo, entre apocalíptico y grotesco, entre el divino bandidaje de Carne de horca (1953) del grandísimo Ladislao Vajda y el experimentalismo del primer Vicente Aranda y su fascinante Fata Morgana (1965), que nunca nos cansamos de ver.

Las últimas palabras de Francisco Umbral, un apasionado del cine que dedicó parte de sus escritos a la crítica cinematográfica -amén del canto de amor por el séptimo arte que es El hijo de Greta Garbo-, pronunciadas el 28 de agosto de 2007 en el lecho de muerte fueron «clasicismo», «romanticismo», «uvas doradas»y «punto». Aquellos cineastas que contemporizaron con el autor de Mortal y rosa guardan profundo parentesco en la sustancia de sus obras y no se pueden encuadrar sin contar con un contexto literario claro y bullente. Hoy el legado de Basilio Martín Patino -como el de Fernán Gómez o Gonzalo Suárez- se hace necesario para entendernos como cultura porque le quitaron la rutina en que había caído a finales de la década de los años 60 y lo levantaron, auxiliados de una impecable sintaxis que recuerda el regalo de la mejor narrativa española: sus uvas doradas.

\section{Referencias bibliográficas}

Heredero, C. y Monterde, J. E. (2003): Los «nuevos cines» en España: ilusiones y desencantos de los años sesenta. Col. Textos, 27. Valencia, Filmoteca Española e Institut Valencià de Cultura. GUBERn, R. y FonT, D. (1975): Un cine para el cadalso. Barcelona, Editorial Euros, 1976.

MARÍAs, M. y MARTínez TORRes, A. (1970): «Entrevista con Fernando Fernán Gómez», Nuestro cine, 94 (febrero), p. 59.

MARTín PAtinO, B. (1968): Nueve cartas a Berta. Madrid, Ciencia Nueva.

SuÁreZ, G. (1991): Don Juan en los infiernos. Oviedo, Caja de Ahorros de Asturias. 